\title{
Antigenic Relationships Among Some Candida Species Studied by Crossed-Line Immunoelectrophoresis: Taxonomic Significance
}

\author{
SYLVIE M. GABRIEL-BRUNEAU ${ }^{1}$ AND ROLAND M. F. GUINET ${ }^{1,2 *}$ \\ Laboratoire de Mycologie, Institut Pasteur de Lyon et du Sud-Est, 69365 Lyon Cedex 2, France, ${ }^{1}$ and Laboratoire de \\ Technologie et d'Immunologie Microbiennes, Département de Microbiologie, Faculté de Pharmacie, 69373 Lyon Cedex 2 , \\ France $^{2}$
}

\begin{abstract}
In crossed immunoelectrophoresis with the corresponding pooled rabbit antisera, Candida tropicalis and Candida albicans antigen preparations produced 65 and 63 immunoprecipitates, respectively. The crossreactions between these antigens and antigens from 15 other yeast strains representing nine species were studied by crossed-line immunoelectrophoresis, using $C$. tropicalis and $C$. albicans antigen-antibody systems as references. We found no qualitative differences between strains of the same species or among the strains of $C$. albicans, Candida stellatoidea, and Candida claussenii. In both the $C$. albicans and $C$. tropicalis reference systems the degrees of cross-reaction between $C$. albicans or $C$. tropicalis and the nine other species revealed the following three groups: $C$. albicans, $C$. tropicalis, $C$. stellatoidea, and $C$. claussenii, which shared 85 to $100 \%$ of their antigens with $C$. albicans and $C$. tropicalis; Candida parapsilosis, Candida guilliermondii, and Candida sake, which shared 50 to $70 \%$ of their antigens with $C$. albicans and C. tropicalis; and Candida utilis, Candida pseudotropicalis, Candida krusei, and Candida zeylanoides, which shared about $30 \%$ of their antigens with $C$. albicans and $C$. tropicalis. Some antigens seemed to be species specific, whereas others seemed to be specific for a group of species within the genus Candida and should be useful for rapid identification of medically important yeasts.
\end{abstract}

At one time, morphological and cultural characteristics, as well as biochemical properties, were the principal criteria used in yeast taxonomy. Later, other criteria were found to be useful for species identification. Tsuchiya et al. (39-43) and Hasenclever et al. $(14,15)$ carried out antigenic analyses of yeast cell walls by using agglutination and absorption, and these authors identified several antigenic factors at the yeast surfaces. A new system for yeast classification was proposed based on these factors. The members of the genus Candida were divided into eight serological groups. Numerous discrepancies with the classification of Van Uden and Buckley $(45)$ were noted. Spencer and Gorin $(31,32)$ did the first proton magnetic resonance spectroscopic studies of parietal mannans and found that the proton magnetic resonance spectra of some yeasts were consistent with serological results. The chemical structures of the immunodominant groups of some yeast mannans have been demonstrated by Ballou et al. (5), Yu et al. (51), Suzuki et al. (35), and other workers. Mannose-containing branched polysaccharides have been identified as antigenic determinants. However, the relationships between the immunochemical structures and the antigenic factors of Tsuchiya have not been defined fully (9). Yamada et al. (48-50) have stated that coenzyme Q systems are very useful for classifying yeasts. In the genus Candida the coenzyme Q systems vary from Q-6 to Q-10.

Another approach to yeast species identification is based on nucleic acid analyses. Determinations of the guanineplus-cytosine $(\mathrm{G}+\mathrm{C})$ contents of deoxyribonucleic acids (DNAs) have shown the heterogeneous nature of numerous yeast genera (26-28). Such determinations allow rather coarse comparisons since strains with similar $\mathrm{G}+\mathrm{C}$ contents can appear similar or not related on the basis of the results of DNA-DNA homology experiments (23).

The last method mentioned above has been promising at

\footnotetext{
* Corresponding author
}

the species level, but interspecific relationships cannot always be deduced from DNA complementarity since the percentages of homology between different species in one genus may be very low or very high (29). Comparisons of certain proteins, especially enzymes, have been tried and may elucidate interspecific relationships (22).

Immunological comparison of fungal antigens for taxonomic purposes was introduced many years ago and has been used to study the genus Candida. Gel immunoprecipitation has been widely used as a tool for investigating fungal antigens and the corresponding antibodies. Ouchterlony analyses have revealed as many as 10 antigens (6), immunoelectrophoretic analyses (IEA) have revealed about 15 antigens (7), and quantitative immunoelectrophoresis (QIE), which is a more sensitive and resolvent technique, has allowed the study of more than 60 antigens without previous purification of components (2). QIE was used by Axelsen (2) to study yeast antigens and has been widely used to study bacterial antigens $(8,16-18)$. Syverson et al. (37) studied the mycelial and yeast phase antigens of Candida albicans, Syverson and Buckley (36) studied the soluble cell wall antigens of $C$. albicans, and Huppert et al. (19) studied Blastomyces and Histoplasma antigens. We studied the Candida tropicalis cell wall soluble antigens (12) and the cytoplasmic soluble antigens of $C$. albicans serotype A (10). The purpose of the present work was to study different species of the genus Candida by immunologically comparing proteins. We established two different antigen-antibody reference systems, one with $C$. tropicalis, which is the type species of the genus, and one with $C$. albicans, which is medically the most important yeast in humans. We compared the antigens from nine other Candida species in each reference system. We used a QIE method involving crossed immunoelectrophoresis (CIE) with an intermediate gel containing a second antigen (or crossed-line immunoelectrophoresis [CLIE]); this method showed reactions of complete or partial identity between individual proteins in complex antigenic mixtures. 


\section{MATERIALS AND METHODS}

Yeast strains. We studied 17 strains representing 11 species; these strains were supplied by the Centraalbureau voor Schimmelcultures (Delft, The Netherlands), the Institut Pasteur de Paris, the National Institutes of Health, and the Institut Français du Pétrole (Table 1).

Antigens. The yeasts were grown for $48 \mathrm{~h}$ at room temperature on a New Brunswick gyratory shaker in one of the following media: Sabouraud yeast broth $(30 \mathrm{~g}$ of Sabouraud Institut Pasteur Production per liter, $3 \mathrm{~g}$ of yeast extract [Difco Laboratories] per liter) or yeast malt broth ( $3 \mathrm{~g}$ of malt extract [Oxoid Ltd.] per liter, $5 \mathrm{~g}$ of peptone [Difco] per liter, $10 \mathrm{~g}$ of glucose per liter, $3 \mathrm{~g}$ of yeast extract [Difco] per liter). For $C$. tropicalis and $C$. albicans the antigens obtained in the two types of broth showed no qualitative differences when they were compared by CLIE. The yeasts were harvested by centrifugation for $15 \mathrm{~min}$ at $15,000 \times g$ and the cellular paste obtained was washed twice with PBS buffer (pH 7.2; 7.650 g of $\mathrm{NaCl}$ per liter, $0.724 \mathrm{~g}$ of $\mathrm{Na}_{2} \mathrm{HPO}_{4}$ per liter, $0.210 \mathrm{~g}$ of $\mathrm{KH}_{2} \mathrm{PO}_{4}$ per liter). To a $70-\mathrm{ml}$ flask (Braun Melsungen) $50 \mathrm{~g}$ of glass beads (diameter, $0.5 \mathrm{~mm}$ ) was added, along with 12 to $20 \mathrm{~g}$ (wet weight) of yeast suspended in $25 \mathrm{ml}$ of PBS buffer. The flask was shaken in a Braun homogenizer for 2 min at $2,800 \mathrm{rpm}$, using liquid $\mathrm{CO}_{2}$ as a cooling agent. The extract was centrifuged for 1 to $2 \mathrm{~h}$ at $48,000 \times g$, filtered through a membrane filter (pore diameter, $0.45 \mu \mathrm{m}$ ), and freeze-dried. The colloid concentration of the extract was determined by refractometry, using human serum as a reference (2).

Antisera. Antisera were produced by immunizing four rabbits, two with a $C$. tropicalis IFP 104 extract and two with a $C$. albicans IP 886 extract, essentially as described by Harboe and Ingild (13) but with some modifications. On days $0,14,28$, and 42 , each rabbit received a mixture of $1 \mathrm{ml}$ of

TABLE 1. Strains studied, G+C contents, coenzyme $Q$ systems, and the colloid concentration of each antigen

\begin{tabular}{|c|c|c|c|}
\hline Strain $^{a}$ & $\begin{array}{l}\text { Coenzyme } \\
\text { Q system }\end{array}$ & $\underset{(\mathrm{mol} \%)}{\mathrm{G}+\mathrm{C} \text { content }}$ & $\begin{array}{l}\text { Colloid } \\
\text { concn } \\
\text { (g/liter) }\end{array}$ \\
\hline C. albicans $3153 \mathrm{~A}(=\mathrm{IP} 884)$ & 9 & $34.9^{c}$ & 20 \\
\hline C. albicans NIH A207 & 9 & $34.9^{c}$ & 24 \\
\hline C. albicans CBS $562^{\mathrm{T}}$ & 9 & $34.9^{c}$ & 18 \\
\hline C. albicans 3156B (= IP 886) & 9 & $34.9^{c}$ & 30 \\
\hline C. albicans NIH B526 & 9 & $34.9^{c}$ & 32 \\
\hline C. claussenii CBS $1949^{\mathrm{T}}$ & 9 & $36.8,35.4^{c, d}$ & 40 \\
\hline C. guilliermondii CBS $566^{\mathrm{T}}$ & 9 & $46.3^{d}$ & 36 \\
\hline C. krusei CBS $573^{\mathrm{T}}$ & 7 & $39.6^{e}$ & 26 \\
\hline C. parapsilosis CBS $604^{\mathrm{T}}$ & 9 & $40.8^{e}$ & 38 \\
\hline C. pseudotropicalis CBS $607^{\mathrm{T}}$ & 6 & $41.3^{e}$ & 38 \\
\hline C. sake CBS 617 & 9 & $38.8^{f}$ & 18 \\
\hline C. stellatoidea CBS $1905^{\mathrm{T}}$ & 9 & $35.7^{e}$ & 40 \\
\hline C. stellatoidea CBS 2990 & 9 & $35.7^{e}$ & 28 \\
\hline C. tropicalis CBS $94^{\mathrm{T}}$ & 9 & $36.1^{d}$ & 38 \\
\hline C. tropicalis IFP 104 & 9 & $36.1^{d}$ & 36 \\
\hline C. utilis CBS $621^{\mathrm{T}}$ & 7 & $45.8^{e}$ & 38 \\
\hline C. zeylanoides CBS $619^{\mathrm{T}}$ & 9 & $57.6^{e}$ & 26 \\
\hline
\end{tabular}

${ }^{a}$ CBS, Centraalbureau voor Schimmelcultures, Delft, The Netherlands; IP, Institut Pasteur, Paris, France; NIH, National Institutes of Health, Bethesda, Md.; IFP, Institut Français du Pétrole, Lyon, France.

${ }^{b}$ Data from reference 49 .

${ }^{c}$ Data from reference 28 .

${ }^{d}$ Data from reference 24 .

${ }^{e}$ Data from reference 33 .

${ }^{f}$ Data from reference 23 . antigen solution and $1 \mathrm{ml}$ of muramyl dipeptide (Institut Pasteur Production) intradermally at several points on its back. Every month, $45 \mathrm{ml}$ of blood was taken, the animals having received an antigen-muramyl dipeptide mixture 8 days before the bleeding. Antibody titers were estimated by line immunoelectrophoresis (21). The sera from months 5 to 11 ( $C$. albicans) or months 4 to 13 (C. tropicalis) were combined; these serum pools were the pools used in this study and were freeze-dried.

QIE methods. CIE was performed by the method of Weeke (46), using a 1\% agarose gel (Pharmacia A) in $0.025 \mathrm{M}$ tris(hydroxymethyl)aminomethane-barbital buffer ( $\mathrm{pH} \mathrm{8.6)}$. First-dimension electrophoresis of the Candida antigens (10 $\mu \mathrm{l}$ ) was performed at $15^{\circ} \mathrm{C}$ by applying $10 \mathrm{~V} / \mathrm{cm}$ for $70 \mathrm{~min}$, and second-dimension electrophoresis was performed at $15^{\circ} \mathrm{C}$ by applying $2 \mathrm{~V} / \mathrm{cm}$ for $18 \mathrm{~h}$ through a gel containing 10 $\mu \mathrm{l}$ of antiserum per $\mathrm{cm}^{2}$. In the first-dimension electrophoresis, the plates were $11 \mathrm{~cm}$ long and $9 \mathrm{~cm}$ wide, and the thickness of the gel was $0.15 \mathrm{~cm}$; in the second-dimension electrophoresis, the plates were $10 \mathrm{~cm}$ long, $10 \mathrm{~cm}$ wide, and $0.1 \mathrm{~cm}$ thick. Line immunoelectrophoresis was performed as described by Kroll (21). The antigen was mixed with $1 \%$ buffered agarose and poured to obtain a gel that was 1 by 20.5 by $0.13 \mathrm{~cm}$ on a glass plate $(11$ by $20.5 \mathrm{~cm})$. Then antibody-containing gels ( 7 by 2 by $0.10 \mathrm{~cm}$ ) were poured along the antigen gel. A blind gel covered the remaining part of the plate. The antibody and antigen concentrations in the gels were $10 \%$, and the electrophoresis conditions used were the same as described above for the second dimension of CIE. CLIE was performed as described by Kroll (20). The first dimension was done as described above for CIE, using $10 \mu \mathrm{l}$ of Candida antigen. A slab (10 by $2 \mathrm{~cm}$ ) was transferred to a coated glass plate $(10$ by $10 \mathrm{~cm})$. A blind gel $(10$ by 2 by $0.13 \mathrm{~cm}$ ) was poured along the first-dimension electrophoresis gel. After congelation a gel strip $(10$ by $1 \mathrm{~cm})$ was cut out of the blind gel and replaced with a gel containing $10 \%$ antigen. The antibody-containing gel was formed by pouring $6 \mathrm{ml}$ of agarose containing $C$. albicans or $C$. tropicalis antiserum into the remaining part of the glass plate. The antiserum concentration and the second-dimension electrophoresis conditions were as described above for CLIE. CLIE with adsorption of antibodies in situ was performed just as CLIE was, except that the amount of antigen in the gel was increased from three- to sixfold; all of the other parameters were the same as for CLIE.

The non-precipitated proteins were always removed by pressing the gel and washing it for $1 \mathrm{~h}$ in buffered saline and then for $15 \mathrm{~min}$ in distilled water. After a new pressing and drying, the plates were stained for $5 \mathrm{~min}$ in a solution of $0.5 \%$ (wt/vol) Coomassie brilliant blue $\mathrm{R}$ in ethanol-acetic acidwater $(45: 10: 45)$. The excess dye was removed by repeated washing in an ethanol-glacial acetic acid-water destainer $(25: 10: 45)(47)$.

\section{RESULTS}

The colloid concentrations of antigens varied from 18 to 60 $\mathrm{g} /$ /iter. The most concentrated antigens were diluted to about 38 to $40 \mathrm{~g} /$ liter (Table 1). C. albicans and C. tropicalis antisera were obtained by pooling for each rabbit the serum samples that produced at least 25 precipitates in line immunoelectrophoresis gels. We detected 65 individual precipitates in the immunoplates run with $C$. tropicalis antibodies. These precipitates were numbered, beginning with 1 at the anodic end of the first-dimension electrophoresis gel (Fig. 1). In the same way, 63 precipitates were numbered on the $C$. albicans system immunoplates (Fig. 2). 

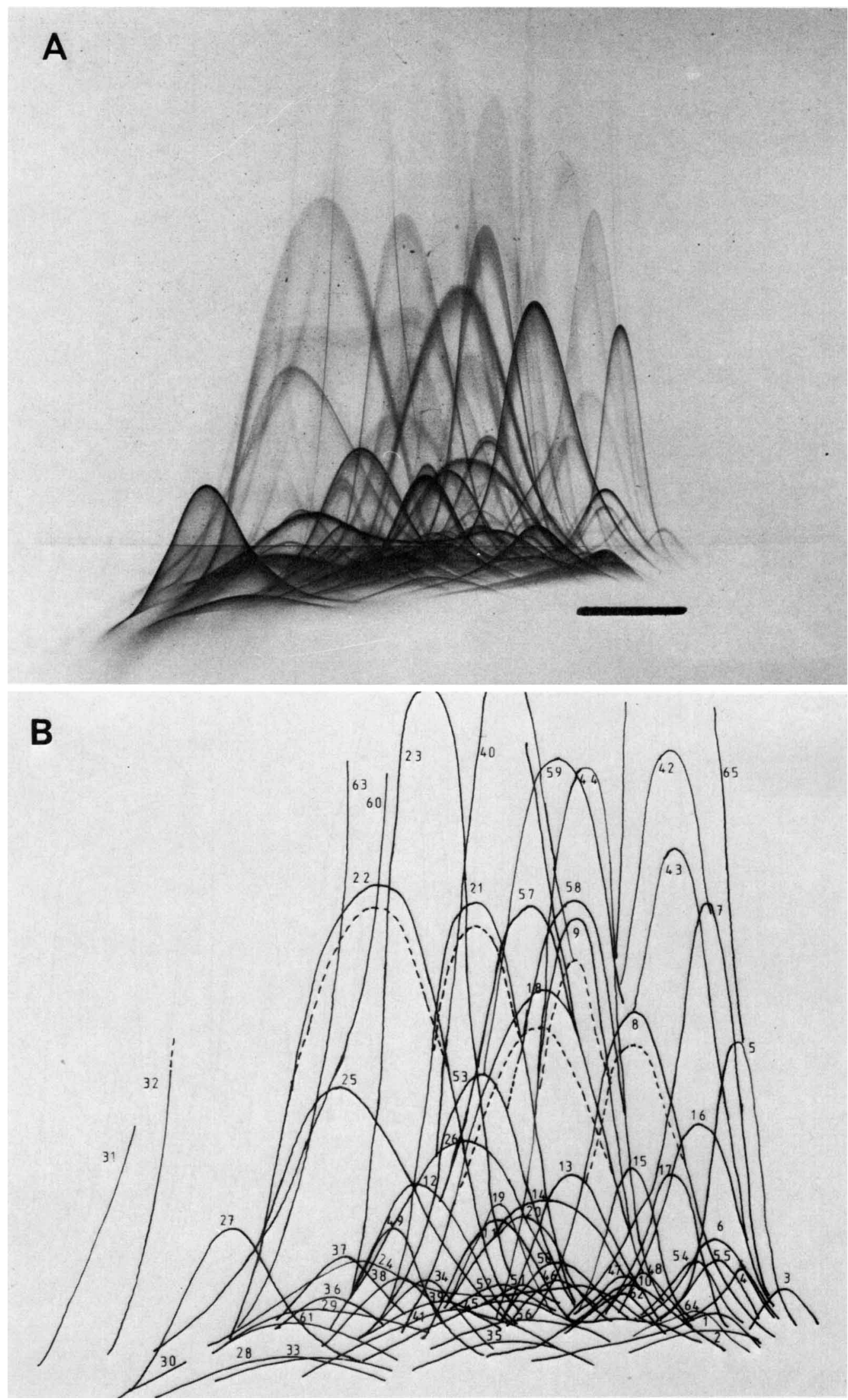

FIG. 1. CIE reference pattern of $C$. tropicalis. (A) Coomassie brilliant blue-stained glass plate. The antigen was $10 \mu$ of $C$. tropicalis IFP 104 reference extract in the cathodic well, and the antibody was $10 \mu \mathrm{l}$ of rabbit antiserum against an extract of $C$. tropicalis $(C$. tropicalis reference serum) per $\mathrm{cm}^{2}$. (B) Drawing of the 65 precipitates that regularly occurred in repeated CIE runs. 

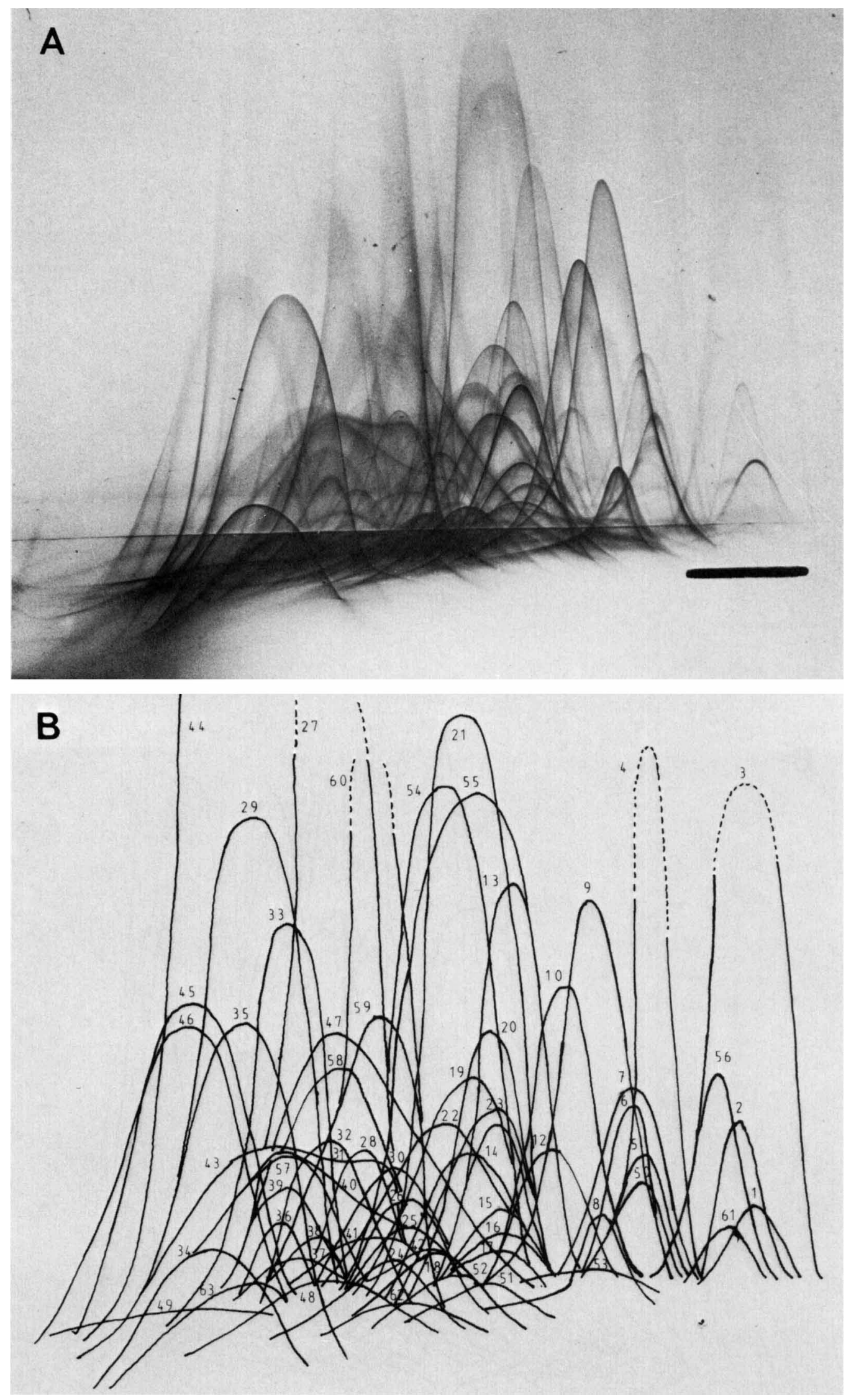

FIG. 2. CIE reference pattern of $C$. albicans. (A) Coomassie brilliant blue-stained glass plate. The antigen was $10 \mu$ l of $C$. albicans IP 886 reference extract in the cathodic well, and the antibody was $10 \mu \mathrm{l}$ of rabbit antiserum against an extract of $C$. albicans $(C$. albicans reference serum) per $\mathrm{cm}^{2}$. (B) Drawing of the 63 precipitates that regularly occurred in repeated CIE runs. 
The degrees of cross-reaction between antigenic mixtures from $C$. tropicalis and 10 other antigens were studied by using CLIE and $C$. tropicalis serum (Fig. 3). In the same way, CLIE was also used in the $C$. albicans system with 13 antigens (Fig. 4). The cross-reactive antigens (which showed reactions of total or partial identity) were numbered in each
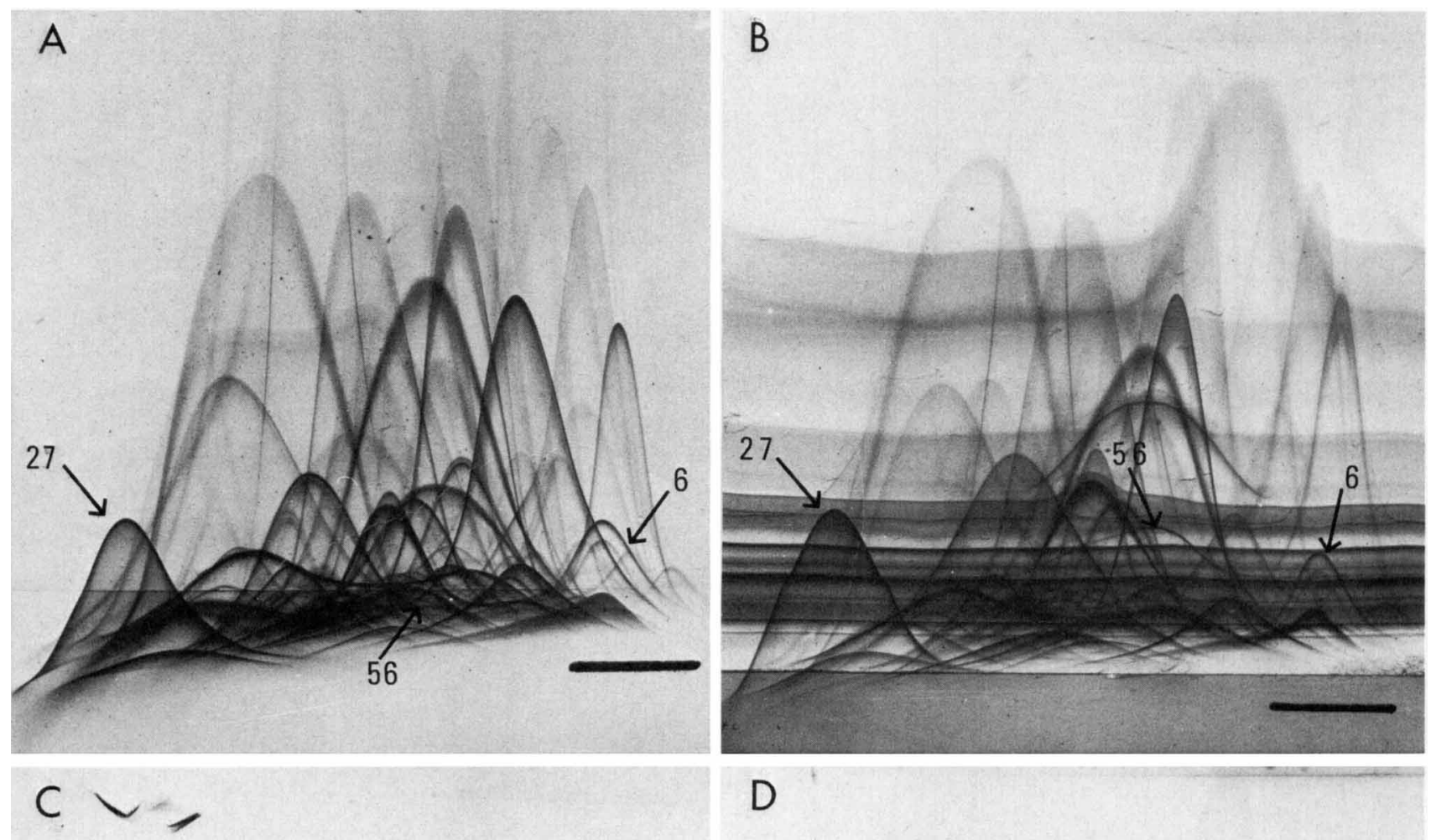

D
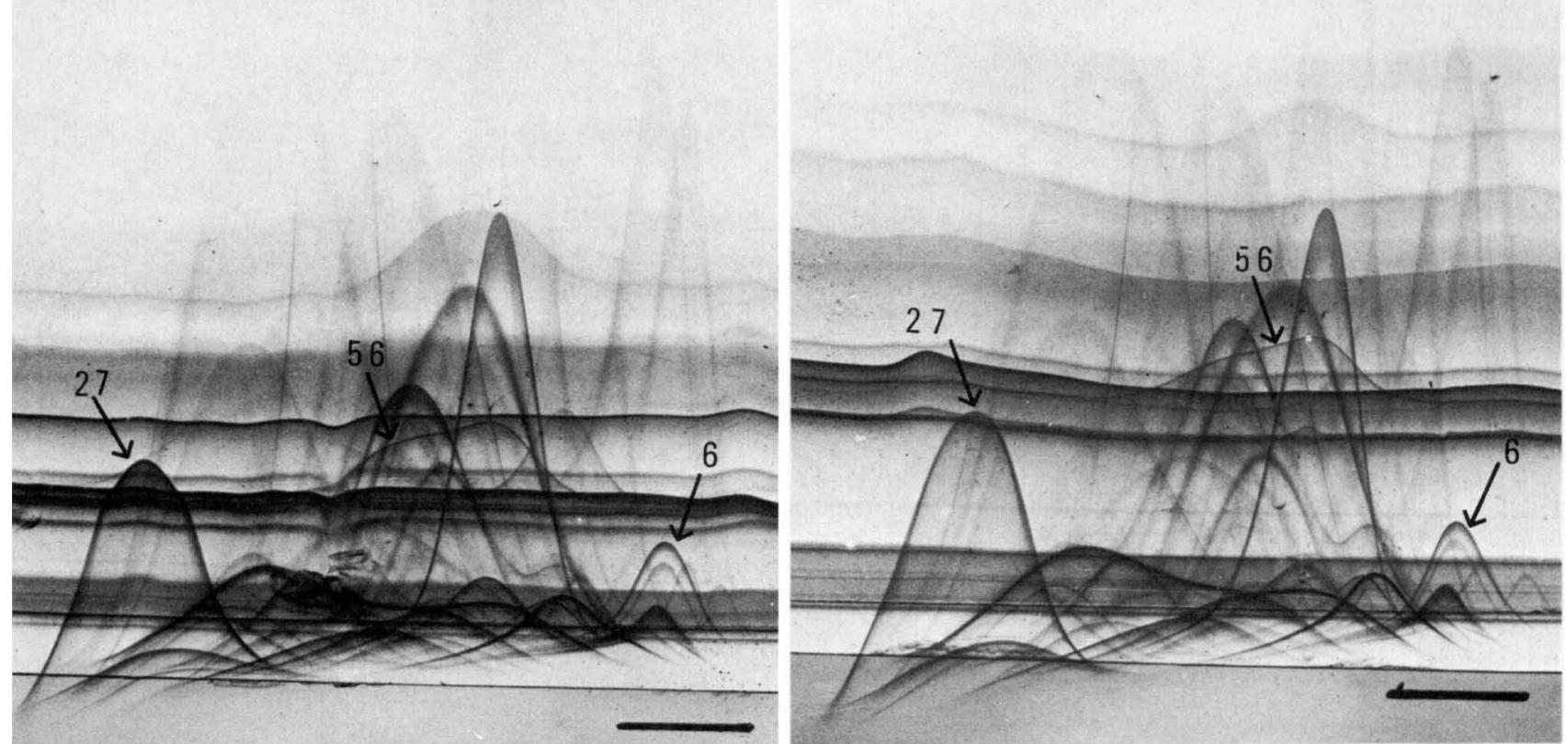

FIG. 3. Antigenic comparison between extracts from $C$. tropicalis and $C$. parapsilosis by using CLIE and $C$. tropicalis antiserum. The antigen was $10 \mu \mathrm{l}$ of $C$. tropicalis IFP 104 extract in the cathodic well. The intermediate gel was a blind gel (A) or contained $50 \mu \mathrm{l}(\mathrm{B}), 100 \mu \mathrm{l}$ (C), or $150 \mu \mathrm{l}$ (D), of $C$. parapsilosis extract. The antibody was $10 \mu l$ of $C$. tropicalis reference serum per $\mathrm{cm}^{2}$ for each plate. Three types of reactions are shown. In the reactions showing identity, the antigen applied to the intermediate gel caused a horizontal precipitation line which fused with the precipitation peak originating from the antigen applied to the well (e.g., peak 56); increasing the antigenic concentration in the intermediate gel resulted in anodic migration of the corresponding precipitates (compare gels $\mathrm{B}, \mathrm{C}$, and D). In the reactions showing partial identity, the antigen applied to the intermediate gel caused a horizontal precipitation line which fused only partially with the precipitation peak or caused an increase in area of the same peak (e.g., peak 27). In the reactions showing lack of identity, some peaks were unaffected by the application of an antigenic mixture in the intermediate gel (e.g., peak 6). No change occurred in 22 of the 65 antigens of the $C$. tropicalis reference pattern; $C$. tropicalis IFP 104 and $C$. parapsilosis CBS $604^{\mathrm{T}}$ shared $66 \%$ of the proteins studied, and these two strains are therefore related. 

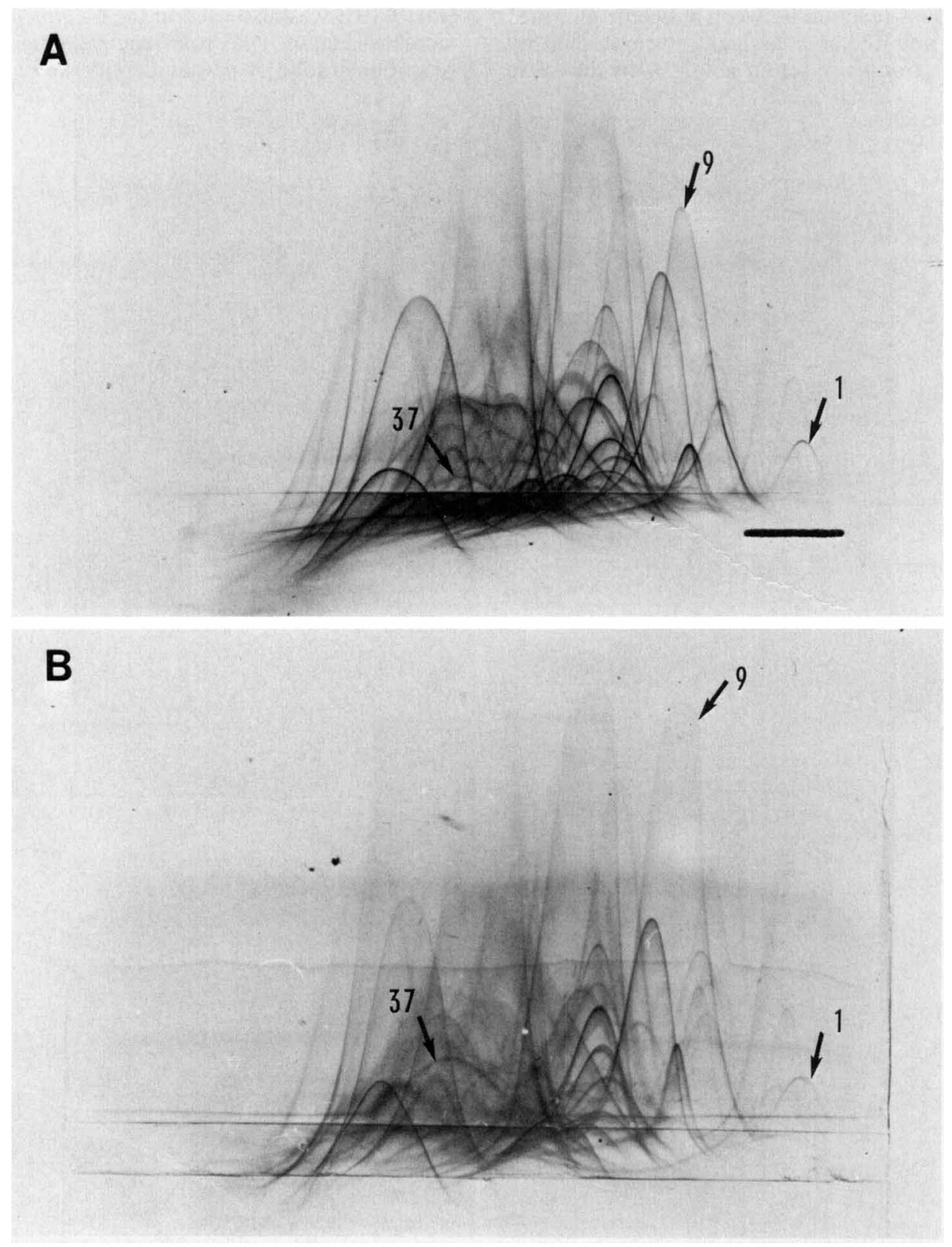

FIG. 4. Antigenic comparison between extracts from $C$. albicans and $C$. krusei by using CLIE and C. albicans antiserum. The antigen was $10 \mu \mathrm{l}$ of $C$. albicans IP 886 extract in the cathodic well. The intermediate gel was a blind gel (A) or contained $200 \mu \mathrm{l}$ of $C$. krusei extract (B). The antibody was $10 \mu \mathrm{l}$ of $C$. albicans reference serum per $\mathrm{cm}^{2}$ for each plate. The following three types of reactions are shown (see legend to Fig. 3): identity (e.g., peak 37), partial identity (e.g., peak 9), and lack of identity (e.g., peak 1). No change occurred in 43 of the 63 antigens of the $C$. albicans reference pattern; $C$. albicans IP 886 and $C$. krusei CBS $573^{\mathrm{T}}$ shared only $31.7 \%$ of the proteins studied, and thus these two strains are not related.

case. All of the antigens from $C$. tropicalis IFP 104 (reference system) cross-reacted with the antigens from $C$. tropicalis CBS $94^{\mathrm{T}}$ ( $\mathrm{T}=$ type strain). All of the antigens from $C$. albicans serotype B strain $3156 \mathrm{~B}$ (reference system) crossreacted with the antigens from different $C$. albicans strains (serotypes A and B and strain CBS 562 $2^{\mathrm{T}}$ ), Candida stellatoidea strains and a Candida claussenii strain. With the other species, the percentages of cross-reactive antigens varied from 81.5 to $26.1 \%$ in the $C$. tropicalis system and from 84.1 to $28.5 \%$ in the $C$. albicans system (Tables 2 and 3 ).

\section{DISCUSSION}

In this study we confirmed the superiority of CLIE over other precipitation methods in analyses of microbial extracts since more than 60 antigens were demonstrated in both the $C$. tropicalis and $C$. albicans systems.

We found no qualitative antigenic differences between strains belonging to the same species since five strains of $C$. albicans and two strains of $C$. tropicalis shared common components. The same methods have previously demon- 
TABLE 2. CLIE results in the $C$. tropicalis system

\begin{tabular}{|c|c|c|c|c|c|}
\hline \multirow{2}{*}{ Species } & \multicolumn{2}{|l|}{ Non-cross-reactive antigens } & \multicolumn{2}{|l|}{ Cross-reactive antigens } & \multirow{2}{*}{$\begin{array}{l}\% \text { Of } \\
\text { cross- } \\
\text { reactivity }\end{array}$} \\
\hline & Precipitate no. & Total no. & Precipitate no. & Total no. & \\
\hline C. tropicalis & None & 0 & All & 65 & 100 \\
\hline C. albicans & $\begin{array}{l}3,4,6,9,10,18,23,41,45,46 \\
48,55\end{array}$ & 12 & All other antigens & 53 & 81.5 \\
\hline C. stellatoidea & $\begin{array}{l}3,4,6,9,10,18,23,41,45,46 \\
48,55\end{array}$ & 12 & All other antigens & 53 & 81.5 \\
\hline C. parapsilosis & $\begin{array}{l}1,2,3,4,5,6,9,10,18,23,24 \\
28,36,37,41,45,46,48,52 \\
\quad 55,62,64\end{array}$ & 22 & All other antigens & 43 & 66.1 \\
\hline C. guilliermondii & $\begin{array}{l}1,2,3,4,6,7,9,10,18,21,22 \\
23,24,26,28,29,30,31,32 \\
33,35,36,37,41,45,46,48 \\
52,55,56,62,64,65\end{array}$ & 33 & All other antigens & 32 & 49.2 \\
\hline C. sake & $\begin{array}{l}1,2,3,4,6,9,10,18,22,23 \\
24,25,28,29,31,32,33,35 \\
40,41,42,43,45,46,48,52 \\
54,55,59,61,62,63,64\end{array}$ & 33 & All other antigens & 32 & 49.2 \\
\hline C. pseudotropicalis & All other antigens & 47 & $\begin{array}{l}8,11,13,14,19,26,30,39,42,44,49,51,53,54 \text {, } \\
57,58,60,61\end{array}$ & 18 & 27.6 \\
\hline C. krusei & All other antigens & 48 & $\begin{array}{l}8,11,13,14,19,36,39,42,43,44,47,50,51,54 \\
57,58,59\end{array}$ & 17 & 26.1 \\
\hline C. zeylanoides & All other antigens & 45 & $\begin{array}{l}7,8,11,13,14,19,21,25,26,34,37,42,43,44 \\
53,54,58,59,63\end{array}$ & 20 & 30.7 \\
\hline C. utilis & All other antigens & 46 & $\begin{array}{l}8,11,13,14,15,19,30,34,36,37,38,42,44,47 \\
49,51,53,59,63\end{array}$ & 19 & 29.2 \\
\hline
\end{tabular}

strated no differences between various $C$. albicans strains (2) or different Pityrosporum ovale strains (11). Previously (10), we found qualitative antigenic differences between $C$. albicans strains $3153 \mathrm{~A}$ and $3156 \mathrm{~B}$, which belong to serotypes $\mathrm{A}$ and $B$, respectively. These differences were not corroborated by CIE with an intermediate gel containing the corresponding antisera prepared in rabbits (data not shown). Using CLIE (intermediate gel containing antigen) and more concentrated new antigenic preparations, we found that all of the antigens of the two serotypes cross-reacted, and it is likely that in the first experiments the antigen concentration in the intermediate gel was not sufficient to allow complete adsorption of antibodies. Since the serotype specificity resides in surface parietal mannans (34), our antigenic cellu- lar extracts may have lacked these mannan antigens or may have contained insufficient quantities of them. All of the antigens from $C$. albicans $3156 \mathrm{~B}$ cross-reacted with the antigens from the closely related organisms $C$. stellatoidea and $C$. claussenii. These results agree with those of Bak and Stenderup (4) and Saez and Andrieu (30).

Antigenic comparisons between the $C$. albicans or $C$. tropicalis antigen-antibody system and different species showed three groups of species (Fig. 5). The four species of group I were Candida zeylanoides, Candida utilis, Candida pseudotropicalis, and Candida krusei, which shared only a few components with $C$. tropicalis and $C$. albicans. Group 2, which included Candida parapsilosis, Candida guilliermondii, and Candida sake, constituted an intermediate group

TABLE 3. CLIE results in the $C$. albicans system

\begin{tabular}{|c|c|c|c|c|c|}
\hline \multirow{2}{*}{ Species } & \multicolumn{2}{|l|}{ Non-cross-reactive antigens } & \multicolumn{2}{|l|}{ Cross-reactive antigens } & \multirow{2}{*}{$\begin{array}{l}\% \text { of } \\
\text { cross- } \\
\text { reactivity }\end{array}$} \\
\hline & Precipitate no. & Total no. & Precipitate no. & Total no. & \\
\hline C. albicans (all strains) & None & 0 & AlI & 63 & 100 \\
\hline C. stellatoidea (all strains) & None & 0 & All & 63 & 100 \\
\hline C. claussenii & None & 0 & All & 63 & 100 \\
\hline C. tropicalis & $1,2,3,10,15,17,21,27,44,62$ & 10 & All other antigens & 53 & 84.1 \\
\hline C. parapsilosis & $\begin{array}{l}1,2,3,6,7,10,12,13,15,16,17,21 \\
22,27,28,38,44,56,61,62\end{array}$ & 20 & All other antigens & 43 & 68.2 \\
\hline C. sake & $\begin{array}{l}1,2,3,4,6,7,8,10,11,12,13,15 \\
17,20,21,25,26,27,29,30,34, \\
35,38,42,43,44,53,54,55,61,62\end{array}$ & 31 & All other antigens & 32 & 50.7 \\
\hline C. guilliermondii & $\begin{array}{l}1,2,3,4,6,7,8,10,12,13,15,16 \\
17,18,20,21,25,26,27,29,30 \\
34,35,36,37,38,42,44,51,53 \\
54,55,61,62\end{array}$ & 34 & All other antigens & 29 & 46 \\
\hline C. pseudotropicalis & All other antigens & 45 & $\begin{array}{l}9,13,14,22,24,28,31,32,37,38 \\
41,42,43,45,49,55,57,59\end{array}$ & 18 & 28.5 \\
\hline C. krusei & All other antigens & 43 & $\begin{array}{l}9,13,14,22,24,28,29,31,32,37 \\
38,41,42,43,45,49,55,56,59 \\
63\end{array}$ & 20 & 31.7 \\
\hline
\end{tabular}




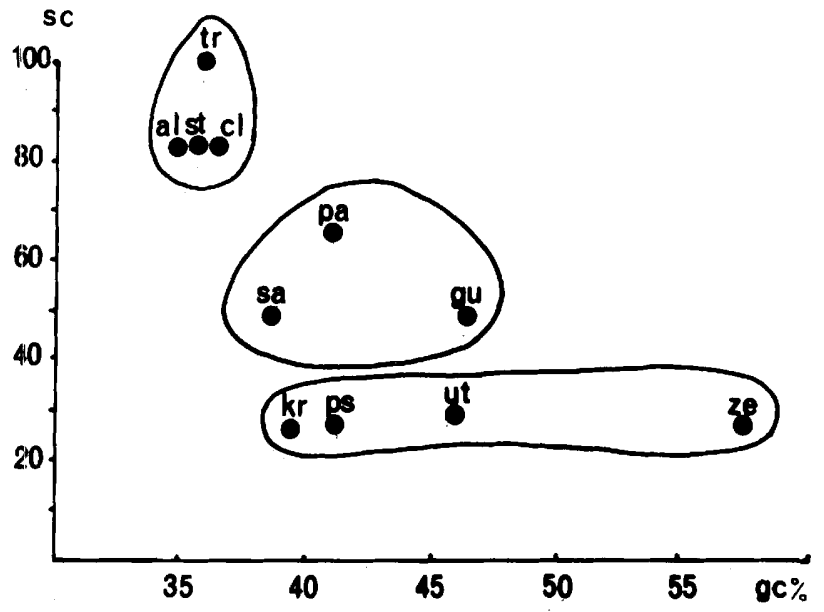

FIG. 5. Comparison between the $\mathrm{G}+\mathrm{C}$ contents ( $\mathrm{gc} \%$ ) and the similarity coefficients (sc) of yeasts in the $C$. tropicalis system. The similarity coefficients were calculated from the numbers of proteins shared by $C$. tropicalis and 10 other yeast species and are expressed as percentages. $\mathrm{tr}, C$. tropicalis; al, $C$. albicans; st, $C$. stellatoidea; $\mathrm{cl}_{\text {, C }}$. claussenii; pa, C. parapsilosis; sa, C. sake; gu, C. guilliermondii; $\mathbf{k r}, C$. krusei; ps, C. pseudotropicalis; ut, $C$. utilis; ze, $C$. zeylanoides.

since $C$.tropicalis and $C$. albicans shared about 50 to $70 \%$ of their antigens with these species. Group 3 included $C$. tropicalis, $C$. albicans, and related species ( $C$. claussenii and $C$. stellatoidea), and close relationships were found in each system (Tables 2 and 3 ). In both systems, some individual antigens cross-reacted totally or partially with the corresponding antigens from all species; these antigens may be common to many yeast species. Other individual antigens were common to only a group of species, and some antigens did not cross-react with any antigen from the species tested and seemed to be species specific (Table 4).

Cross-reactions among $C$. albicans, $C$. tropicalis, and other Candida species have been studied by several workers. In a study by Axelsen (3) in which he used CLIE, the degrees of cross-reaction between $C$. albicans and different species agreed with our results, except the results for $C$. guilliermondii. Other strains of $C$. guilliermondii are being studied to elucidate this discrepancy. In two other studies, in which IEA was used $(7,25)$, the degrees of cross-reaction with $C$. albicans and $C$. tropicalis sera were much lower. These differences could have several origins. IEA is much less sensitive than QIE; in addition, IEA compared 13 (7) or 16 (25) fungal antigens, whereas more than 60 antigens were compared by QIE. Thus, the basis for protein comparison is different in the two techniques; in IEA, similar proteins from

TABLE 4. Antigens in the $C$. tropicalis system ${ }^{a}$

\begin{tabular}{|c|c|}
\hline Antigens common to: & Antigen no. \\
\hline $\begin{array}{l}\text { C. tropicalis, C. albicans, C. stellatoidea, and } \\
\text { C. claussenii }\end{array}$ & $\begin{array}{l}1,2,24,28,52 \\
62,64\end{array}$ \\
\hline $\begin{array}{l}\text { C. tropicalis, } C . \text { albicans, } C \text {. stellatoidea, } C . \\
\text { claussenii, and } C \text {. parapsilopsis }\end{array}$ & $22,29,35$ \\
\hline $\begin{array}{l}\text { C. tropicalis, C. albicans, } C \text {. stellatoidea, } C \text {. } \\
\text { claussenii, C. parapsilopsis, and } C . \text { guillier- } \\
\text { mondii }\end{array}$ & $12,20,27$ \\
\hline All 11 species & $8,11,13,14$ \\
\hline
\end{tabular}

${ }^{a}$ In addition, the following antigens were non-cross-reactive: 3,4 , $6,9,10,18,23,41,45,46,48$, and 55 . different antigenic mixtures are identified only by their positions. CLIE allows direct observation of identity reactions just as the Ouchterlony technique does, but it also offers more information than the Ouchterlony method. Thus, it appears clear that among all gel precipitation techniques, QIE is the most useful technique for antigenic comparisons of complex antigenic mixtures. Other criteria that also have been found to be useful for species identification include agglutination and adsorption, proton magnetic resonance spectroscopic methods, and the structure of the coenzyme Q system. Although these methods also pointed out heterogeneity among numerous yeast genera, mainly in the genus Candida, they allowed only scant comparisons among the 11 species tested; 7 of these species had the same coenzyme $Q$ type, and 5 had similar proton magnetic resonance spectra (31, 49). C. albicans, C. tropicalis, and C. sake could not be distinguished by agglutination-adsorption experiments (41).

The strains which we investigated had $\mathrm{G}+\mathrm{C}$ contents of 34.9 to $57.5 \mathrm{~mol} \%$. Some species with almost identical $\mathrm{G}+\mathrm{C}$ contents such as $C$. tropicalis and $C$. stellatoidea or $C$. parapsilosis and C. pseudotropicalis $(24,33)$, appeared to be clearly different when CLIE and the $C$. tropicalis or $C$. albicans system were used. However, it must be emphasized that species which are very different from the species that are used for antiserum preparation cannot be compared among themselves; four species (C. krusei, $C$. pseudotropicalis, $C$. utilis, and $C$. zeylanoides) with very different $\mathrm{G}+\mathrm{C}$ contents, different coenzyme Q systems, and perfect states belonging to various genera had identical similarity coefficients (Fig. 5). Corresponding antisera should be prepared for the study of these species. Such antisera are under development in our laboratory; we are also performing immunological studies with antigens obtained from several reference strains for each species.

DNA-DNA reassociation is a useful technique that allows strain comparisons at the species level, as has been done for C. tropicalis (24). QIE results have suggested close affinity between species that show no relatedness in DNA-DNA homology studies (for example, $C$. tropicalis and $C$. stellatoidea) $(1,4)$. Van der Walt and Johannsen (44) and Price et al. (29) showed that interbreeding Kluyveromyces species had low levels of sequence similarity. Thus, DNA reannealing experiments can detect only close relationships among the species of one genus. Another approach, immunological comparison of enzymes, was proposed by Lachance and Phaff (22) (i.e., $\beta$-glucanases in the genus Kluyveromyces). QIE allows simultaneous study of more than 50 proteins without previous purification. Many of these proteins are probably enzymes. Tran Van Ky et al. (38) found 14 enzymatic activities in 17 precipitates obtained with $C$. albicans antigen by using immunoelectrophoresis. Since our antigens were prepared in a similar way, most of the antigens compared in our study could be enzymes. QIE seems to be capable of elucidating relationships among the species in a genus. These techniques could allow selection of specific antigens for each species or group of species, which could be used for rapid identification of medically important yeasts.

\section{ACKNOWLEDGMENT}

This work was supported by Pôle Rhône-Alpes de Génie MédicalEtablissement Public Régional as project $\mathbf{8 8 2 7}$.

\section{LITERATURE CITED}

1. Ahearn, D. G., S. A. Meyer, G. Mitchell, M. A. Nicholson, and A. L. Ibrahim. 1977. Sucrose-negative variants of Candida tropicalis. J. Clin. Microbiol. 5:494-496. 
2. Axelsen, N. H. 1973. Quantitative immunoelectrophoretic methods as tools for a polyvalent approach to standardization in the immunochemistry of Candida albicans. Infect. Immun. 7:949_ 960 .

3. Axelsen, N. H. 1976. Analysis of human Candida precipitins by quantitative immunoelectrophoresis. A model for analysis of complex microbial antigen-antibody system. Scand. J. Immunol. 5:177-190.

4. Bak, A. L., and A. Stenderup. 1969. Deoxyribonucleic acid homology in yeasts. Genetic relatedness within the genus $C a n-$ dida. J. Gen. Microbiol. 59:21-30.

5. Ballou, C. E., P. N. Lipke, and W. C. Raschke. 1974. Structure and immunochemistry of the cell wall mannans from Saccharomyces chevalieri, Saccharomyces italicus, Saccharomyces diastaticus, and Saccharomyces carlsbergensis. J. Bacteriol. 117:461-467.

6. Biguet, J., R. Havez, and P. Tran Van Ky. 1959. Les possibilités d'application aux champignons pathogènes de la méthode d'Ouchterlony et de l'immunoélectrophorèse. Mykosen 2:115120.

7. Biguet, J., P. Tran Van Ky, and S. Andrieu. 1963. Etude électrophorétique et immunochimique comparée des antigènes de quelques levures du genre Candida (Candida albicans, Candida stellatoidea, Candida tropicalis, Candida zeylanoides, Candida krusei, Candida pseudotropicalis, Candida macedoniensis). Mycopathol. Mycol. Appl. 17:239-254.

8. Emmett, M., and J. Crowle. 1982. Crossed immunoelectrophoresis: qualitative and quantitative considerations. J. Immunol. Methods 50:65-83.

9. Fukasawa, Y., A. Nishikawa, M. Suzuki, and T. Shinoda. 1980. Immunochemical basis of the serologic specificity of the yeast: immunochemical determinants of several antigenic factors of yeasts. Zentralbl. Bakteriol. Parasitenkd. Infektionskr. Hyg. Abt. 1 Suppl. 8:127-136.

10. Guinet, R., and S. Gabriel. 1980. Candida albicans group Aspecific soluble antigens demonstrated by quantitative immunoelectrophoresis. Infect. Immun. 29:853-858.

11. Guinet, R., and S. Gabriel. 1980. Malassezia (Pityrosporum). Etudes en immunoélectrophorèse quantitative. Bull. Soc. Fr. Mycol. Med. 9:235-240.

12. Guinet, R., S. Gabriel, F. Oriez, and R. Bonaly. 1979. Identification par immunoélectrophorèse bidimensionnelle d'antigènes pariétaux solubles spécifiques de Candida tropicalis. Ann. Microbiol. (Paris) 130B:433-442.

13. Harboe, N., and A. Ingild. 1973. Immunization, isolation of immunoglobulins, estimation of antibody titre. Scand. J. Immunol. 2(Suppl. 1):161-164.

14. Hasenclever, H., and W. Mitchell. 1961. Antigenic studies of Candida. I. Observation of two antigenic groups in Candida albicans, J. Bacteriol. 82:570-573.

15. Hasenclever, H., W. Mitchell, and J. Loewe. 1961. Antigenic studies of Candida. II. Antigenic relation of Candida albicans group B to Candida stellatoidea and Candida tropicalis. J. Bacteriol. 82:574-577.

16. Hertz, J. B., N. Hojby, V. Andersen, and P. Baekgaard. 1976. Crossed immunoelectrophoretic analysis of Bordetella pertussis antigens and of corresponding antibodies in human sera. Acta Pathol. Microbiol. Scand. Sect. B 84:386-394.

17. Hoff, G. E., and N. Hoiby. 1978. Cross reactions between Neisseria meningitidis and twenty-seven other bacterial species. Acta Pathol. Microbiol. Scand. Sect. B 86:87-92.

18. Hoiby, N., J. B. Hertz, and V. Andersen. 1976. Cross reactions between Bordetella pertussis and twenty-eight other bacterial species. Acta Pathol. Microbiol. Scand. Sect. B 84:395-400.

19. Huppert, M., J. P. Adler, E. H. Rice, and S. H. Sun. 1979. Common antigens among systemic disease fungi analyzed by two-dimensional immunoelectrophoresis. Infect. Immun. 23:479-485

20. Kroll, J. 1973. Crossed-line immunoelectrophoresis, p. 79-80. In N. H. Axelsen, J. Kroll, and B. Weeke (ed.), A manual of quantitative immunoelectrophoresis. Methods and application. Blackwell Scientific Publications, Oslo.

21. Kroll, J. 1973. Line immunoelectrophoresis, p. 61-67. In N. H.
Axelsen, J. Kroll, and B. Weeke (ed.), A manual of quantitative immunoelectrophoresis. Methods and application. Blackwell Scientific Publications, Oslo.

22. Lachance, M. A., and H. J. Phaff. 1979. Comparative study of molecular size and structure of exo- $\beta$-glucanases from Kluyveromyces and other yeast genera: evolutionary and taxonomic implications. Int. J. Syst. Bacteriol. 29:70-78.

23. Meyer, S. A., K. Anderson, R. E. Brown, M. T. Smith, D. Yarrow, G. Mitchell, and D. G. Ahearn. 1975. Physiological and DNA characterization of Candida maltosa, a hydrocarbon utilizing yeast. Arch. Microbiol. 104:225-231.

24. Meyer, S. A., and H. J. Phaff. 1972. DNA base composition and DNA-DNA homology studies as tools in yeast systematics, $p$. 375-387. In A. Kockova-Kratochvilova and E. Minarik (ed.), Yeast, models in science and technics. Slovak Academy of Sciences, Bratislava.

25. Montrocher, R. 1980 . Significance of immunoprecipitation in yeast taxonomy: antigenic analysis of some species within the genus Candida. Cell. Mol. Biol. 26:293-302.

26. Nakase, T., and K. Komagata. 1969. DNA base comparison of the genus Hansenula. J. Gen. Appl. Microbiol. 15:85-95.

27. Nakase, T., and K. Komagata. 1970. Significance of DNA base composition in the classification of yeast genus Pichia. J. Gen. Appl. Microbiol. 16:511-521.

28. Nakase, T., and K. Komagata. 1971. Significance of DNA base composition in the classification of yeast genus Candida. J. Gen. Appl. Microbiol. 17:259-279.

29. Price, C. W., G. B. Fuson, and H. J. Phaff. 1978. Genome comparison in yeast systematics: delimitation of species within the genera Schwanniomyces, Saccharomyces, Debaryomyces, and Pichia. Microbiol. Rev. 42:161-193.

30. Saez, H., and S. Andrieu. 1979. Etude mycologique comparée de Candida stellatoidea et Candida albicans. Ann. Parasitol. (Paris) 54:555-565.

31. Spencer, J. F. T., and P. A. J. Gorin. 1969. Systematics of the genus Candida (Berkhout): proton magnetic resonance spectra of the mannans and mannose-containing polysaccharides as an aid in classification. Antonie van Leeuwenhoek J. Microbiol. Serol. 35:33-44.

32. Spencer, J. F. T., and P. A. J. Gorin. 1971. Systematics of the genus Candida (Berkhout): proton magnetic resonance spectra of the mannose-containing polysaccharides of some further species of Candida as an aid in classification. Antonie van Leeuwenhoek J. Microbiol. Serol. 37:75-88.

33. Stenderup, A., and A. L. Bak. 1968. Deoxyribonucleic acid base composition of some species within the genus Candida. J. Gen. Microbiol. 52:231-236.

34. Summers, D. F., A. P. Grollman, and H. F. Hasenclever. 1964. Polysaccharide antigens of Candida cell wall. J. Immunol. 92:491-499.

35. Suzuki, S., H. Sunayama, and T. Saito. 1968. Studies on the antigenic activity of yeasts. I. Analysis of the determinant groups of the mannan of Saccharomyces cerevisiae. Jpn. J. Microbiol. 12:19-24.

36. Syverson, R. E., and H. R. Buckley. 1977. Cell wall antigens in soluble cytoplasmic extracts of Candida albicans as demonstrated by crossed immuno-affinoelectrophoresis with concanavalin A. J. Immunol. Methods 18:149-156.

37. Syverson, R. E., H. R. Buckley, and C. C. Campbell. 1975. Cytoplasmic antigens unique to the mycelial yeast phase of Candida albicans. Infect. Immun. 12:1184-1188.

38. Tran Van Ky, P., T. Vaucelle, S. Andrieu, C. Torck, and F. Floc'h. 1969. Caractérisation de complexes enzymes anti-enzymes dans les extraits de levure du genre Candida après immunoélectrophorèse en agarose. Mycopathol. Mycol. Appl. 38:345-357.

39. Tsuchiya, T., Y. Fukazawa, S. Hayashi, J. Hayashi, and M. Doi. 1957. Serological relationships among ascosporogenous and asporogenous yeasts. Jpn. J. Microbiol. 1:125-131.

40. Tsuchiya, T., Y. Fukazawa, and S. Kawakita. 1965. Significance of serological studies on yeast. Mycopathol. Mycol. Appl. 26:115

41. Tsuchiya, T., Y. Fukazawa, M. Taguchi, T. Nakase, and T. 
Shinoda. 1974. Serologic aspects of yeast classification. Mycopathol. Mycol. Appl. 53:77-91.

42. Tsuchiya, T., F. Iwahara, F. Miyasaki, and Y. Fukazawa. 1954. Studies on the classification of the genus Candida. I. Antigenic analysis of seven species of the genus Candida. Jpn. J. Exp. Med. 24:95-103.

43. Tsuchiya, T., and M. Taguchi. 1980. Antigenic relationship among various yeasts. Zentralbl. Bakteriol. Parasitenkd. Infektionskr. Hyg. Abt. 1 Suppl. 8:137-146.

44. Van der Walt, J. P., and Z. Johannsen. 1979. A comparison of infertility and in vitro DNA-DNA reassociation as criteria for speciation in the genus Kluyveromyces. Antonie van Leeuwenhoek J. Microbiol. Serol. 45:281-291.

45. Van Uden, N., and H. Buckley. 1971. Genus 2, Candida Berkhout, p. 893. In J. Lodder (ed.), The yeasts. A taxonomic study, 2nd ed. North-Holland Publishing Co., Amsterdam.

46. Weeke, B. 1973. Crossed immunoelectrophoresis, p. 47-56. In N. H. Axelsen, J. Kroll, and B. Weeke (ed.), A manual for quantitative immunoelectrophoresis. Methods and application. Blackwell Scientific Publications, Oslo.

47. Weeke, B. 1973. General remarks on principles, equipment, reagents and procedures, p. 15-35. In N. H. Axelsen, J. Kroll, and B. Weeke (ed.), A manual for quantitative immunoelectrophoresis. Methods and application. Blackwell Scientific Publications, Oslo.

48. Yamada, Y., M. Arimoto, and K. Kondo. 1976. Coenzyme Q system in the classification of apiculate yeasts in the genera Nadsonia, Saccharomycodes, Hanseniaspora, Kloeckera and Wickerhamia. J. Gen. Appl. Microbiol. 22:293-299.

49. Yamada, Y., and K. Kondo. 1972. Taxonomic significance of coenzyme $Q$ system in yeasts and yeastlike fungi, p. 363-373. In A. Kockova-Kratochvilova and E. Minarik (ed.), Yeasts, models in science and technics. Slovak Academy of Sciences, Bratislava.

50. Yamada, Y., T. Okada, O. Ueshima, and K. Kondo. 1973. Coenzyme $Q$ system in the classification of the ascosporogenous yeast genera Hansenula and Pichia. J. Gen. Appl. Microbiol. 19:189-208.

51. Yu, R., C. T. Bishop, F. P. Cooper, H. F. Hasenclever, and F. Blank. 1967. Structural studies of mannans from Candida albicans (serotype A and serotype B), Candida parapsilosis, Candida stellatoidea and Candida tropicalis. Can. J. Chem. 45:22052211. 